\title{
Adecuaciones específicas en el peso de la mochila escolar de los estudiantes de la Unidad Educativa Manuel
} Echeandia de la provincia de Guaranda, Ecuador.

Specific adaptations in the weight of the school backpack of the students of the Manuel Echeandia Educational Unit of the province of Guaranda, Ecuador.

Raynier Montoro Bombú ${ }^{1}$, Byron Enrique Mora Aviléz ${ }^{2}$, Lincoln José Adolfo Torres Valencia $^{3}$, Luis Ricardo Villacis Monar ${ }^{4}$

\begin{abstract}
.
DOI: https://doi.org/10.33262/cienciadigital.v3i1.307

The area of student welfare is one of the most important for the development of a student's corporal and aesthetic health. With the objective of adapting the weight of the school backpack of the students of the Manuel Echeandia educational unit of the province of Guaranda. Ecuador. For the development of this prospective crosssectional study of a quantitative and qualitative nature, theoretical methods were used, such as analysis and synthesis, deduction induction, and the survey was used as an empirical method. The Omron hbf 214 scale measuring body composition was used as a tool for data collection. The sample selected was $100 \%$ of students attending the Higher Basic Education. Of them $34.57 \%$ belong to the male sex and the remaining $65.43 \%$ are female, all in ages between 11 to 14 years, in addition tools were used for the collection of information such as surveys focused on the research of the weight of school backpacks. After measuring the body weight of each of the students involved and buying them with the weight of the students with the school backpack put: The average weight of the students is $9.48 \mathrm{~kg}$ and the average weight is obtained as the main results. of school backpacks in girls does not vary according to the weight of boys. Thus, it is very necessary to establish specific adjustments for the sample studied. As fundamental conclusions are obtained: The need to reduce the weight of the school

1 Universidad Técnica de Ambato. Carrera de Cultura Física y Pedagogía de la Actividad Física, Ambato, Ecuador.r.montoro@uta.ed.ec

2 Universidad Técnica de Ambato. Carrera de Cultura Física y Pedagogía de la Actividad Física, Ambato, Ecuador. byrforce1@hotmail.com

${ }^{3}$ Universidad Estatal de Guaranda. Facultad de Ciencias de la Educación, Guaranda, Ecuador lincoln.torresvalencia@ hotmail.com

${ }^{4}$ Universidad Estatal de Guaranda. Facultad de Contabilidad Auditoria y Administración, Guaranda, Ecuador, rvillacism@hotmail.com
\end{abstract}


backpack of the students of this educational unit since in relation to the body weight they are too heavy and the possible causes of the back pain and the pathologies in relation to the corporal and aesthetic health of the students.

Keywords: School backpack. Back ailments in children. Body weight in children.

\section{Resumen.}

El área de bienestar estudiantil es uno de los más importantes para el desarrollo de una salud corporal y estética de los estudiantes. Con el objetivo de adecuar el peso de la mochila escolar de los estudiantes de la unidad educativa Manuel Echeandia de la provincia de Guaranda. Ecuador. Para el desarrollo de este estudio de tipo transversal prospectivo de naturaleza cuantitativa y cualitativa se utilizaron métodos teóricos como el análisis y síntesis, la inducción deducción y como método empírico se utilizó la encuesta. Como herramienta para la recolección de datos se utilizó la báscula Omron hbf 214 que medía composición corporal. La muestra seleccionada fue del $100 \%$ de estudiantes de cursan la Educación Básica Superior. De ellos el $34.57 \%$ pertenecen al sexo masculino y la restante $65.43 \%$ son del sexo femenino, todos en edades entre 11 a 14 años, además se utilizaron herramientas para el levantamiento de información como las encuestas enfocadas a la investigación del peso de las mochilas escolares. Después de medir el peso corporal cada uno de los estudiantes involucrados y comprarlos con el peso de los estudiantes con la mochila escolar puesta: Se obtienen como principales resultados el peso promedio de los estudiantes es de $9,48 \mathrm{~kg}$ por otro lado el promedio del peso de mochilas escolares en niñas no varía en función con el peso de los varones. Siendo así muy necesario establecer adecuaciones específicas para la muestra estudiada. Como conclusiones fundamentales se obtienen: La necesidad de disminuir el peso de la mochila escolar de los estudiantes de esta unidad educativa ya que con relación al peso corporal estas están demasiado pesadas y se evidencia las posibles causas del dolor de espalda y las patologías con relación a la salud corporal y estética de los estudiantes.

Palabras clave: Mochila escolar. Dolencias de espalda en niños. Peso corporal en niños. 


\section{Introducción.}

\section{Conclusiones.}

\section{Referencias bibliográficas.}

\section{PARA CITAR EL ARTÍCULO INDEXADO.}

Montoro R., Mora B., Torres L. \& Villacis L., (2018) Adecuaciones específicas en el peso de la mochila escolar de los estudiantes de la Unidad Educativa Manuel Echeandia de la provincia de Guaranda, Ecuador. Revista electrónica Ciencia Digital 2(3), 281-291. Recuperado desde: http://www.cienciadigital.org/revistascienciadigital/index.php/CienciaDigital/article/view/7 $\underline{0 / 65}$

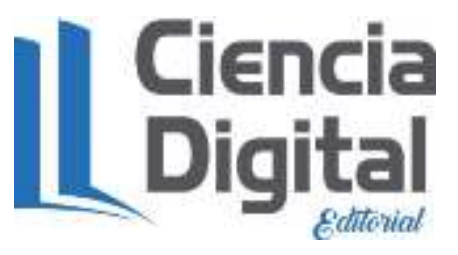

El artículo que se publica es de exclusiva responsabilidad de los autores y no necesariamente reflejan el pensamiento de la Revista Ciencia Digital.

El artículo queda en propiedad de la revista y, por tanto, su publicación parcial y/o total en otro medio tiene que ser autorizado por el director de la Revista Ciencia Digital. 

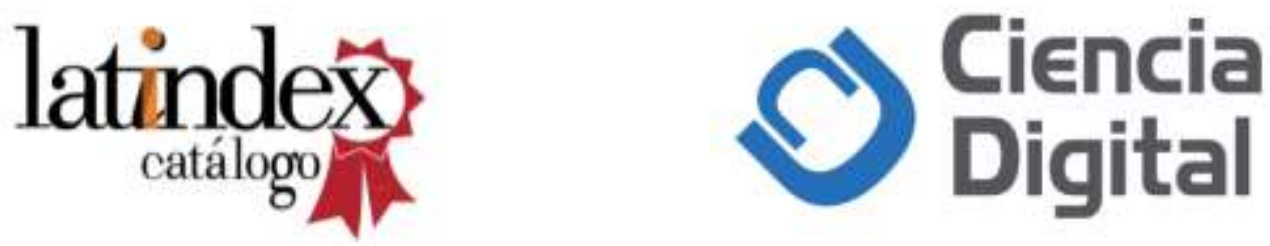